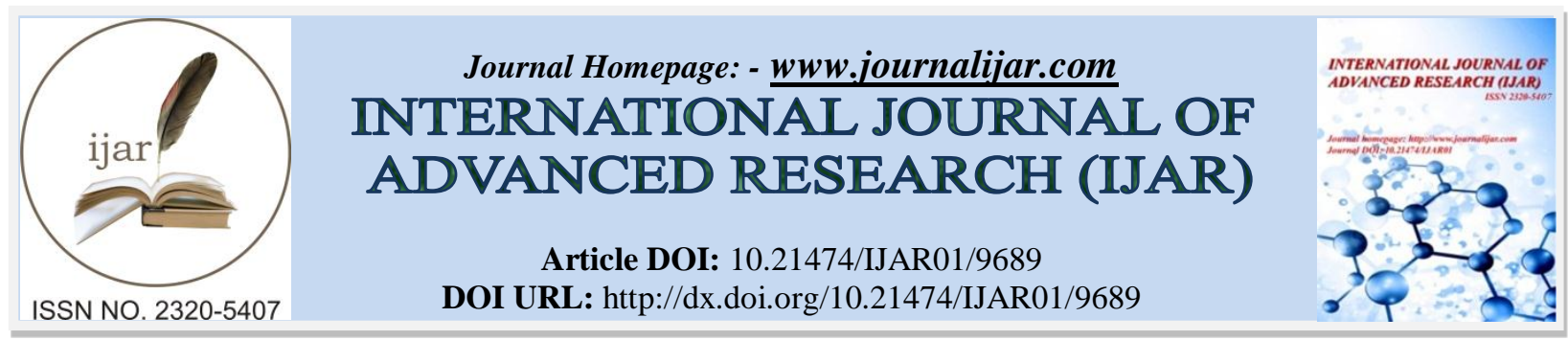

RESEARCH ARTICLE

\title{
ANALYSIS OF FACTORS INFLUENCE NURSES STRESS LEVEL WORK OF XYZ COMPANY IN QATAR.
}

\section{Tri Sukmono ${ }^{1}$, Syahfirin Abdullah ${ }^{2}$ and Kohar Sulistyadi ${ }^{2}$.}

1. Student Magister Program Study Occupational Health, Safety and Environment, Post Graduate School, Sahid University Jakarta.

2. Lecture of Post Graduate School, Sahid University Jakarta.

\section{Manuscript Info}

Manuscript History

Received: 06 July 2019

Final Accepted: 08 August 2019

Published: September 2019

Key words:-

Nurse, Stress, SEM PLS.

\section{Abstract}

Introduction: The nursing profession has potential to experience stress in the workplace and face pressure in the medical environment caused by various stressors.

The nurse's great responsibility to the client can increase work stress on the nurse, so that both directly and indirectly will cause an increase in stress on the nurse.

Aim: To analyze the factors that influence the work stress level of XYZ company nurses in Qatar.

Method: Type of research is observational with correlational type of description. The number of respondents was 152 nurses in the XYZ Company, conducted in July - August 2019. Data was obtained from collecting nurses' demographic characteristics and DASS 42 questionnaire in which consisted of three scales to measure 3 types of emotional states, namely depression, anxiety, and stress. Each scale consists of 14 questions, analyzed by Structural Equation Modeling (SEM) based on Partial Least Square (PLS) with smartpls 3.0 program. Result: The result found that $73.68 \%$ of respondents had normal, $3.29 \%$ of respondents had mild stress levels, $6.58 \%$ of respondents had moderate stress levels, $9.87 \%$ of respondents had severe stress levels and $6.58 \%$ respondents have extremely severe stress levels. From the PLS analysis the results show that the $\mathrm{p}$ value $<0.05$ influence of age 0.024 , education 0.017 , marital status 0.020 , family status 0,000 , work experience 0.003 and length of work 0,000 , all Ho is rejected meaning that they are factors that influence the stress level of nurses while gender 0.621 and position of Job 0.657 with $\mathrm{p}$ value $>0.05$ and Ho is not rejected, meaning they are not a factor of affects the level of stress nurses.

Conclusion: Age, education, marital status, family status, work experience and work duration, significant factors of stress among nurses in XYZ companies. Gender and job position are not significant factor of stress among nurses in XYZ companies. Contribution of age to stress was $10.4 \%$, contribution of level education to stress $16.8 \%$, contribution marital status to stress $24 \%$, contribution family status to stress $33.9 \%$, contribution length of work to stress $20.3 \%$ and contribution work experience to stress $19.8 \%$. 


\section{Introduction:-}

Nurses as one of the professions that have an important role in the delivery of health services. The main task of a nurse is to treat patients to accelerate the healing process. Because of its dynamic work, it needs to have a good body condition, healthy, and have enough energy. The nursing profession is a profession that has the potential to experience stress in the workplace and face pressure in the medical environment caused by various stressors (Botha et al 2015).

Nurses as individuals tend to experience work-related stress when there is a perception of threat and an inability to overcome problems (Chetty et al 2016).

A study conducted in India by Chaudhari et al (2018) mentioned that about $87.6 \%$ of nurses experienced stress, $1.5 \%$ of nurses experienced mild stress and $34 \%$ experienced moderate stress, $20.6 \%$ of nurses reported moderate levels and $9,3 \%$ reported a high level of somatic complaints and there was a significant positive correlation between the severity of stress and somatic symptoms.

Botha et al (2015) state that $80 \%$ of nurses who experience more work stress, may suffer from depression and as much as $75 \%$ are likely to cause chronic illness.

Salam (2016) In his research conducted in the Kingdom of Saudi Arabia (KSA) explaining that work stress shows the majority of participating health care professionals report moderate to high stress levels, and the overall prevalence of work stress is $66.2 \%$.

Nurses stress also occurs at XYZ companies. Such conditions can be caused by internal and external factors. Internal factors such as high work demands, relationships with colleagues, company policy. The external factors such as the work environment with extreme weather, cultural differences. Statistic data from HealthCare Occupational Health section company shows that cases of stress and other general symptoms such as headaches, fever, flu, back pain, musculoskeletal disorders or injuries cause sickness absent. Data shows that the number of sickness absent in 2017 was $1.84 \%$ and the total sick days were 35124 days from the number of employees of 8617 people. The data also states that the Department of Health Safety Environment and Business Services ranks first at 5.63\%.

From the description above, the authors are interested in conducting research. The purpose of this study was to analyze the factors that influence nurses' stress levels in the XYZ Company.

\section{Literature review}

Stress is defined as a dynamic condition in which an individual is faced with opportunities, demands, or resources related to what the individual desires and whose results are seen as uncertain and important (Robbins \& Judge, 2017). In accordance with the definition of stimulus, stress can also be interpreted as a state of environmental demands that exceed the capacity of the usual and require more response so that it can affect the physical and psychological on someone.

(Bamuhair, 2015). Stress is an unspecified body response, from both pleasant and unpleasant circumstances (Kaplan \& Sadock, 2015). Stress is caused by internal and external demands that disrupt individual balance and affect physical and psychological comfort (Annamalai \& Nandagopal, 2014).

\section{Types of Job Stress}

(Annamalai \& Nandagopal, 2014) classifies work stress into 3 categories, namely:

1. Physical stress

2. Psychic or emotional stress (psychological strain)

3. Behavioral stress

According to Pambudi Tama \& Hardiningtyas (2017), there are 4 types of stress, namely:

1. Eustress, is a positive stress that gives rise to creative endeavors. When you need inspiration, eustress can add energy to do it. 
2. Distress, a type of negative stress, which generally occurs when the mind is Uncomfortable with changes from routine and really needs more familiar Routines, distress is divided into two types, namely acute stress (arises suddenly due to changes in routine and the bias disappears quickly), and chronic stress (arising continuously due to changes in routine that occur, and can have an impact on physical and mental health).

3. Hyperstress, is a negative stress that arises when someone is forced to run more than needed. Employees who like challenging work will experience positive stress, but when the extra work is excessive, experiencing overtime work without reward, can cause hyperstress. This stress can lead to emotional and physical effects.

4. Hypostress, is the opposite of hyperstress. A condition where a person experience boredom continuously. For example, someone who accepts work that is easy and not challenging, routine work continuously, causing loss of inspiration andenthusiasm for work.

\section{Symptoms of Job Stress}

(Robbins \& Judge, 2017) group symptoms of work stress into three aspects that is:

\section{Physiological symptoms}

1. Stomach ache,

2. Increased heart rate and shortness of breath,

3. Blood pressure rises,

4. Headache,

5. Heart attack.

\section{Psychological symptoms}

1. Worry,

2. Tension,

3. Boredom,

4. Dissatisfaction at work,

5. Irritability,

6. Procrastinating.

\section{Behavioral Symptoms}

1. Increased dependence on alcohol and cigarette consumption,

2. Doing sabotage at work,

3. Overeating or reducing unnatural eating as withdrawal behavior

4. Absenteeism increases and work performance decreases,

5. Restlessness and experiencing sleep disturbance,

6. Speak fast

\section{Factors that influence Work Stress}

According to (Robbins \& Judge, 2017), there are three potential sources of stress, including:

\section{Environmental Factors}

1. Economic uncertainty

2. Political uncertainty

3. Uncertainty in technology

\section{Organizational Factors}

1. Task demands

2. Role demands

3. Interpersonal demands

\section{Personal factors}

1. Family

2. The economy

3. Personality

According to Hasibuan (2016) factors that cause employee stress include difficult and excessive workload, the pressure and attitude of the leadership is not fair and reasonable, inadequate time and work equipment, conflicts between individuals and leaders or work groups, reward for services that are too low, family matters. Gibson, et al 
(2019) explain the causes of work stress (work stressors) consisting of physical, individual, group, and organizational environmental stressors.

\section{Effect of Stress}

Some studies that report negative impacts experienced by nurses due to work stress include; research conducted by Berger, et al (2015) says that fatigue experienced by nurses can endanger physical, social, emotional, spiritual and intellectual harm to nurses that can have a negative impact on patients and organizations.

According to Hamer, et al (2012) said that stress can be at risk for many emotional health problems, such as anxiety, depression and post-traumatic stress disorder.

According to Coetzee \& Klopper (2010) Mention that stress can also have an impact on physical health problems including lack of energy so it is prone to accidents. The same study about the effects of stress according to Heraclides, et al (2012); Konturek, Brzozowski, \& J, (2011) said that fatigue caused by stress can result in increased inflammatory processes, hypertension, coronary artery disease, diabetes, obesity and gastrointestinal disorders and can result in losses for a health organization. Other impacts caused by stress on nurses are not only detrimental in terms of health but also affect the desire to stop working, decrease activity and turnover. Patient care becomes ineffective, carelessness and ignorance of patients and co-workers occurs, medical errors, patients receive unprofessional treatment results and low patient satisfaction. Berger, et al (2015).

\section{Method of the research:-}

Type of research is observational with correlational type of description. The number of respondents was 152 nurses in the XYZ Company, conducted in July - August 2019. Data was obtained from collecting nurses' demographic characteristics and DASS 42 questionnaire in which consisted of three scales to measure 3 types of emotional states, namely depression, anxiety, and stress. Each scale consists of 14 questions, analyzed by Structural Equation Modeling (SEM) based on Partial Least Square (PLS) with smartpls 3.0 program.

According to Lovibond \& Lovibond (1995) Scores from depression, anxiety, and stress are calculated by adding up scores for relevant items. The items on the depression scale are questions number 3, 5, 10, 13, 16, 17, 21, 24, 26, 31, $34,37,38,42$. The anxiety scale items questions number $2,4,7,9,15,19,20,23,25,28,30,36,40,41$, and stress scale items are questions number $1,6,8,11,12,14,18,22,27,29,32,33,35,39$ with the answer choices 0 - 3 . No 0 at all, 1 sometimes, 2 often, and 3 very often. The subject answers every question. After answering all the questions, Table 3.1 the score from the scale is accumulated so that the total score for the depression, anxiety, and stress scale is as follows:

Table 3.1:-Depression, Anxiety and Stress Scale Score

\begin{tabular}{|l|l|l|l|}
\hline Kategori & \multicolumn{1}{|c|}{ Depression } & \multicolumn{1}{|c|}{ Anxiety } & Stress \\
\hline Normal & $0-9$ & $0-7$ & $0-14$ \\
\hline Mild & $10-13$ & $8-9$ & $15-18$ \\
\hline Moderate & $14-20$ & $10-14$ & $19-25$ \\
\hline Severe & $21-27$ & $15-19$ & $26-33$ \\
\hline Extremely Severe & $28+$ & $20+$ & $34+$ \\
\hline
\end{tabular}

Source: Psychology Foundation of Australia

Data analysis techniques in this study include descriptive and quantitative analysis techniques. The following is an explanation of each of the data analysis techniques:

\section{Descriptive Analysis Techniques}

Descriptive analysis techniques in this study were done by making a frequency distribution table and calculating the average value of each indicator on the research variables. The frequency distribution table is made on the demographic data of the respondents, while the calculation of the mean value is used to provide a description of the work stress of nurses based on the results of filling out the questionnaire.

\section{PLS SEM Analysis Technique}

In this study, the analysis of factors affecting the work stress of nurses in XYZ companies will be analyzed using Structural Equation Modeling (SEM) analysis techniques based on Partial Least Square (PLS) with the help of the smartpls3 program. 
Based on the operational definition of the research variable, the nurse's characteristics variable consisting of variables of gender, age, education, work experience, marital status, family status, position and length of work are categorical data. According to the DASS 42 questionnaire containing 14 question items to measure work stress variables. Based on the description, Figure 3.1 The SEM model form that will be used to identify the factors that influence work stress in this study are as follows:

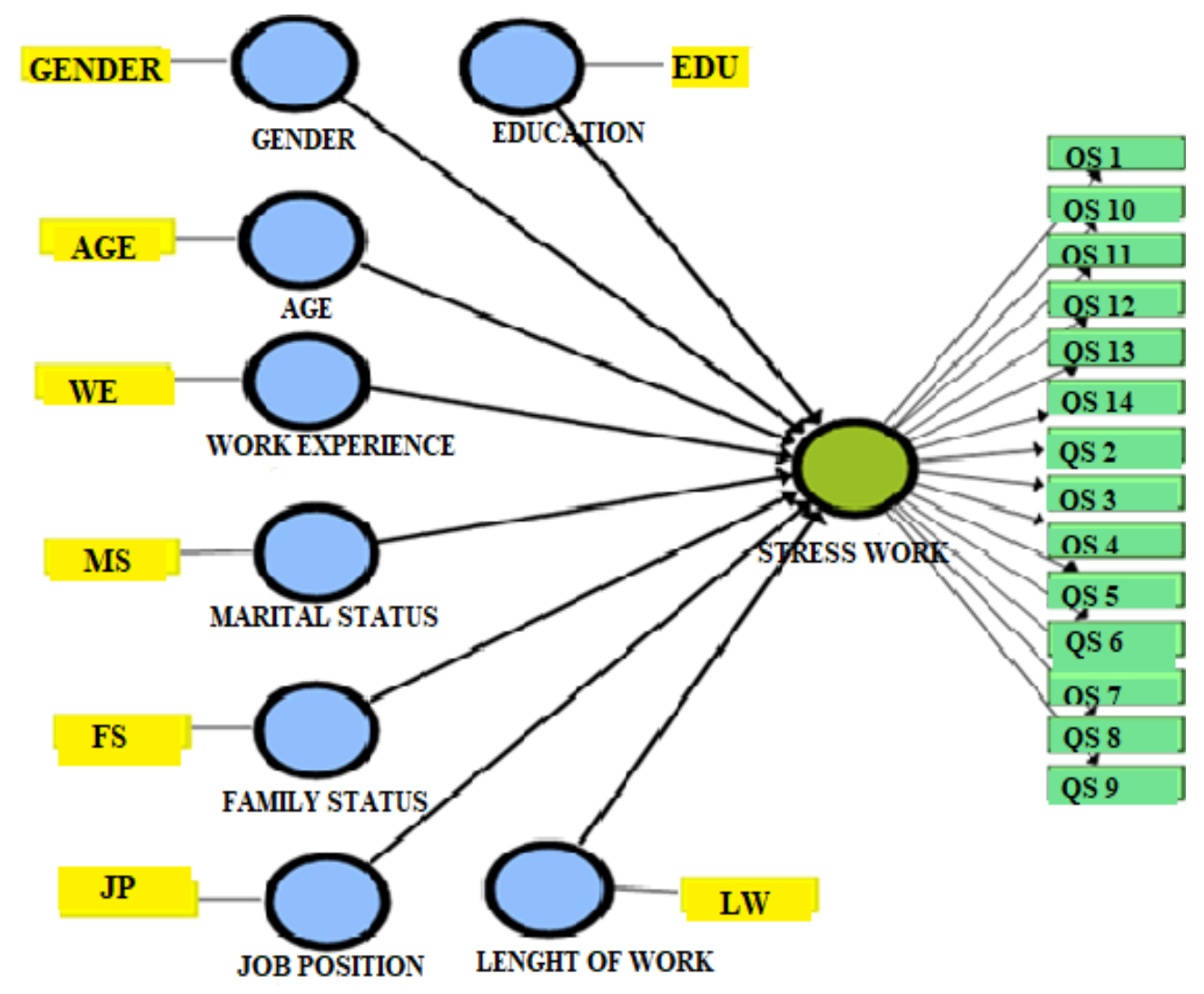

Figure 3.1:-Specification of SEM PLS Model

Source: Data processed with Smartpls (2019)

The stages in PLS analysis include the external model testing, the goodness of fit model and the internal model testing. Here is a discussion of each of the stages in the PLS analysis:

\section{Outer Model Testing}

The testing phase of the measurement model includes testing for Convergent Validity, Discriminant Validity and Composite Reliability. The results of the PLS analysis can be used to test the research hypothesis if all the indicators in the PLS model have met the requirements of convergent validity, discriminant validity and composite reliability.

\section{Testing the Goodness of fit Model}

After fulfilling the validity and reliability of the construct at the outer model testing stage, the test continues on the Goodness of fit model testing. Fit PLS model can be seen from the SMRM value of the model. The PLS model is stated to have met the criteria of goodness of fit model if the SRMR value $<0.10$ and the model declared perfect fit if the SRMR value $<0.08$.

\section{Inner Model Testing}

Testing the inner model involves testing the significance of direct influence.

Significance of the direct effect test is used to test the effect of exogenous variables on endogenous variables. 


\section{Result and discussion:- \\ Brief of view}

Descriptive analysis of respondent characteristics, The number of respondents in this study were 152 respondents. All respondents are employees of XYZ companies, The following are the results of the descriptive analysis of respondents' characteristics based on:

\section{Gender}

The majority of respondents were male (58.6\%), while the remaining $41.4 \%$ of respondents were female.

\section{Age}

The majority of respondents aged $>40$ years $(37.5 \%)$, while the remaining $21.1 \%$ were respondents aged $<20$ years, as many as $23 \%$ of respondents aged $21-30$ years and $18.4 \%$ of respondents aged $31-40$ years.

\section{Education}

In this study most of the respondents had a Bachelor of Nursing education (40.8\%) while the remaining 26.3\% of respondents were Nursing School $29.6 \%$ of the respondents were Diploma and 3.3\% of respondents had Master degrees.

\section{Length of working}

The most of the respondents had worked in this company for $>10$ years $(71.7 \%)$, while the remaining $5.3 \%$ of respondents worked 1-5 years and $23 \%$ of respondents worked for 6-10 years.

\section{Job Position}

The most of the respondents were nursing staff (75\%), while the remaining $14 \%$ of respondents were senior nurses and $10.5 \%$ of respondents were chief nurses.

\section{Work experience}

The majority of respondents have had work experience in their fields for > 10 years $(51.3 \%)$, while the remaining $10.5 \%$ of respondents have <5 years of work experience and as many as $38.2 \%$ of respondents have work experience between 6-10 years.

\section{Family Status}

The most of the respondents in this study were live alone $19.7 \%$, live with husband or wife $15.1 \%$, stay with husband / wife and 1 child $25 \%$, staying with husband or wife, children etc. $40.1 \%$.

\section{Marital status}

The most respondents were married (93\%) while the remaining 7\% respondents were nurses who were married but did not bring a family at the work location.

Descriptive analysis of Nurse Stress Levels, based from 152 respondents studied in this study most of the respondents had stress levels in the normal category (73.68\%), while the remaining $3.29 \%$ of respondents had stress levels in the mild category, as many as $6.58 \%$ of respondents had stress levels in moderate category, as many as $9.87 \%$ of respondents had stress levels in the severe category and as many as $6.58 \%$ of respondents had stress levels in the extremely severe category.

In Figure 4.1 shows the results of the estimated work stress variables, where all indicators already have a loading factor value above 0.7 so that the model meets the convergent validity requirements 


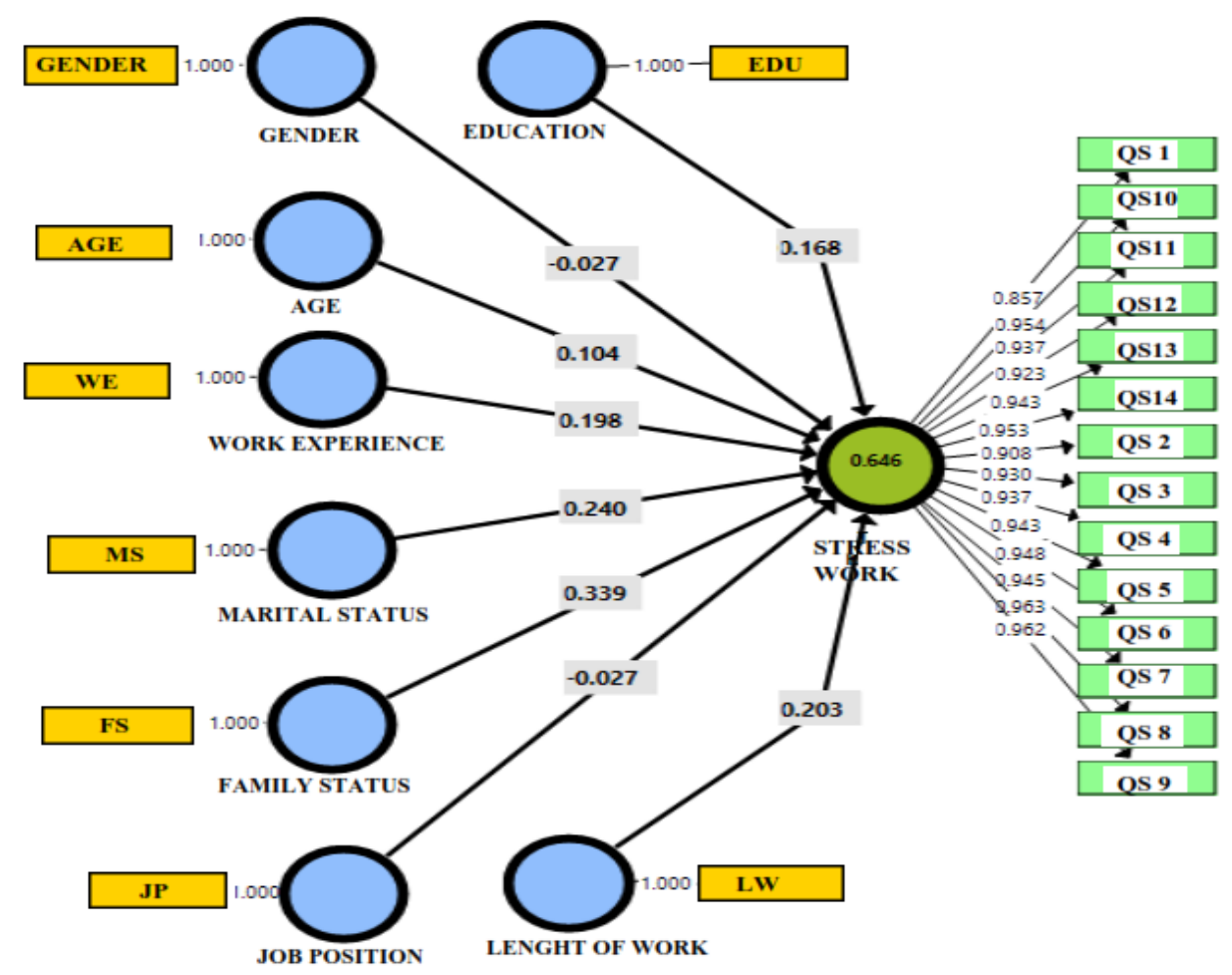

Figure 4.1:-Results of estimation of the PLS - algorithm model

\section{Discussion:-}

Based on the results of the PLS analysis, the results show that the p value of the effect of gender on work stress is 0.621 with a statistical $\mathrm{T}$ of 0.495 . By $\mathrm{p}$ value $>0.05$ and $\mathrm{T}$ statistic $<1.96$, Ho is not rejected and it is concluded that gender is not a factor influencing nurses' stress levels in XYZ companies. This can be caused because most respondents in this study were respondents who were male. The results of this study indicate that gender did not significantly influence nurses' stress levels. The results of this study are in line with the results of research conducted by Jaradat (2017) stated that there is no evidence of gender differences in relation to nurse stress.

The $\mathrm{p}$ value of the effect of age on work stress is 0.024 with a statistical $\mathrm{T}$ of 2.264 . By p value $<0.05$ and $\mathrm{T}$ statistic> 1.96 and regression coefficient positive, Ho is rejected and it is concluded that age is a factor that influences the level of stress of nurses in XYZ company. This study is in line with the results of an investigation conducted by Safarpour, et al (2018) mentioning that the relationship between work stress and demographic variables shows a significant correlation between work stress with age, marital status, work experience.

Value of $\mathrm{p}$ value of the influence of education on work stress Is equal to 0.017 with a statistical $\mathrm{T}$ of 2.390 . By $\mathrm{p}$ value $<0.05$ and $T$ statistic $>1.96$ as well as a positive coefficient of regression, Ho was rejected and concluded that education was a factor influencing nurses' stress levels in XYZ companies. According to Hasan (2017) in his study there was a statistically significant difference between depression and the characteristics of nurses, with graduates from the Nursing School and working in the night shift. It was also mentioned that the potential reason for stress might be related to many responsibilities, lack of educational qualifications.

The $\mathrm{p}$ value of the influence of marital status on work stress is 0,000 with a statistical $\mathrm{T}$ of 2,327 . By $\mathrm{p}$ value $<0.05$ and T statistic $>1.96$ as well as a positive coefficient of regression, Ho was rejected and concluded that marital status was a factor influencing nurses' stress levels in XYZ companies. The results of this study are in line with the opinion of Olatunji \& Mokuolo (2014) which shows that in health workers, marital status influences work stress. Married 
workers tend to have low work stress compared to unmarried workers because married workers have emotional support from their partners. Similar results to the study of Alenezi et al (2018) stated that nurse marital status is a significantly identified factor that contributes to stress.

The $\mathrm{p}$ value of the influence of family status on work stress is 0,000 with a statistical $\mathrm{T}$ of 4,090 . By $\mathrm{p}$ value $<0.05$ and $\mathrm{T}$ statistic $>1.96$ and regression coefficient positive, Ho is rejected and it is concluded that family status is a factor that influences the level of stress of nurses in XYZ companies. The results of this study are in line with opinions with Cheung \& Yip (2015) stating that there is a positive correlation between depression or stress with family status, marital status and job dissatisfaction.

The value of $\mathrm{p}$ value of the influence of position on work stress is 0.657 with a statistical $\mathrm{T}$ of 0.445 . By $\mathrm{p}$ value $>$ 0.05 and $\mathrm{T}$ statistic < 1.96 and regression coefficient positive, Ho is not rejected and it is concluded that position is not a factor that influences the level of stress of nurses in XYZ companies. This can be caused because in this study most of the respondents were nursing staff or executors followed by Senior Nurse and at least Chief Nurse. In line with research conducted by Widoretno (2018) states that position has no relationship with work stress.

The $\mathrm{p}$ value of the influence of work experience on work stress is 0.003 with a T statistic of 2.941 . By $p$ value $<0.05$ and $\mathrm{T}$ statistic $>1.96$ and regression coefficient positive, Ho is rejected and it is concluded that work experience is a factor influencing nurses' stress levels in XYZ companies. The results of this study agreed with Al Rasasi, et al (2015) in their study that more than $73.4 \%$ of nurses in Dubai experience severe stress levels where they actually have long work experience.

The $\mathrm{p}$ value of the effect of work duration on work stress is 0,000 with a statistical $\mathrm{T}$ of 3.521 . By $\mathrm{p}$ value $<0.05$ and T statistic $>1.96$ and regression coefficient positive, Ho is rejected and it is concluded that length of work is a factor that influences nurses' stress levels in XYZ companies. This study is in line with the results of Stanetic \& Tesanović's (2013) study which states that length of work and age have important effects on stress levels and burnout syndrome, also in line with research conducted by Li S, et al (2016) states that nurses who have experience working for many years and are exposed to worrying events, they are more sensitive to stress compared to the initial time in undergoing his career.

\section{Conclusion and recommendation:-}

Level stress of nurses XYZ company were: $73.68 \%$ normal, 3.29\% mild stress levels, 6.58\% moderate stress levels, 9.87\% severe stress levels and 6.58\% extremely severe stress levels. Age, education, marital status, family status, work experience and work duration, significant factors of stress among nurses in XYZ companies. Gender and job position, not significant factor of stress among nurses in XYZ companies.

Contribution of age to stress was $10.4 \%$, contribution of level education to stress $16.8 \%$, contribution marital status to stress $24 \%$, contribution family status to stress $33.9 \%$, contribution length of work to stress $20.3 \%$ and contribution work experience to stress $19.8 \%$.

Based on the results of the study, the suggestions from the authors are: Effective and creative stress management is needed in the form of counseling, time management and refreshing or regular work leave with family to reduce work stress. The presence of family (wife, children) is very necessary and plays an important role in accompanying the husband (male nurse) to create physical and spiritual peace.

\section{References:-}

1. Abdul, S. (2016). Job Stress and Job Satisfaction Among Health Care Professionals, Qatar Foundation Annual Research Conference Proceedings 2016: HBOP2571 http://dx.doi.org/10.5339/qfarc.2016. HBOP2571. Hamad bin Khalifa University Press (HBKU Press)

2. Al Rasasi A., Al Faisal W., El Sawaf E., Hussain H., dan Wasfy A. (2015). Work Related Stress Among Nurses Working in Dubai, a Burden for Healthcare Institutions. American Journal of Psychology and Cognitive Science Vol. 1, No. 2, 2015, pp. 61-65. http://www.aiscience.org/journal/ajpcs

3. Alenezi, A.M., Aboshaiqah, A., Baker, O. (2018). Work-related stress among nursing staff working in government hospitals and primary health care centres. Int J Nurs Pract. 2018 Oct;24(5):e12676. doi: 10.1111/ijn.12676 
4. Annamali, S., \& Nandagopal, R. (2014). Occupational Stress: A Study of Employee Stress in Indian ITES Industry (p. 165). New Delhi: Allied Publishers.

5. Bamuhair, S., FArhan, A., Alhubaiti, A., Agha, A., Rahman, S., \& Ibrahim, N. (2015). Sources of stress and coping strategies among undergraduate medical students enrolled in a problem-based learning curriculum. Journal of Biomedical Education, Volume 2015, Article ID 575139, 8 pages http://dx.doi.org/10.1155/2015/575139 Hindawi Publishing Corporation

6. Berger, J., Polivka, B., Smoot, E. A., \& Owens, H. (2015). Compassion Fatigue in Pediatric Nurses.Journal of Pediatric Nursing, 30(6), e11-e17. https://doi.org/10.1016/j.pedn.2015.02.005

7. Borkowski, N. (2015). Manajemen Pelayanan Kesehatan. Perilaku Organisasi. Edisi 2 Jakarta. ECG

8. Botha, E., Gwin, T., \& Purpora, C. (2015). The effectiveness of mindfulness based programs in reducing stress experienced by nurses in adult hospital settings: a systematic review of quantitative evidence protocol. JBI Database of Systematic Reviews and Implementation Reports, 13(10), 21-29. https://doi.org/10.11124/jbisrir2015-2380

9. Chaudhari AP, Mazumdar K, Motwani YM, Ramadas D. (2018). A profile of occupational stress in nurses. Ann Indian Psychiatry 2018;2:109-14. DOI: 10.4103/aip.aip_11_18

10. Chetty, P. J., Coetzee, M., \& Ferreira, N. (2016). Sources of job stress and cognitive receptivity to change: the moderating role of job embeddedness. South African Journal of Psychology, 46(1), 101-113. https://doi.org/10.1177/0081246315591308

11. Cheung, T. \& Yip, P.S.(2015). Depression, Anxiety and Symptoms of Stress among Hong Kong Nurses: A Cross-sectional Study. Int J Environ Res Public Health. 2015 Sep 7;12(9):11072-100. doi: 10.3390/ijerph120911072.

12. Coetzee, S. K., \& Klopper, H. C. (2010). Compassion fatigue within nursing practice: Aconcept analysis. Nursing and Health Sciences, 12(2),235-243. https://doi.org/10.1111/j.14422018.2010.00526.x

13. Gibson, J. L., Ivancevich, J. M., Donnelly, Jr., J. H., \& Konopaske, R. (2019). Managing organizational behavior. New York, NY: McGraw-Hill Education

14. Hamer, M., Endrighi, R., Venuraju, S. M., Lahiri, A., \& Steptoe, A. (2012). Cortisol responses to mental stress and the progression of coronary artery calcification in healthy men and women. PLoS ONE,7(2), 1-6. https://doi.org/10.1371/journal.pone.0031356

15. Hasan, A. A. (2017). Work Stress, Coping Strategies and Levels of Depression among Nurses Working in Mental Health Hospital in Port-Said City, Int Arch Nurse Health Care 2017, 3:068 DOI: 10.23937/2469$5823 / 1510068$

16. Hasibuan, Malayu, S.P. (2016). Manajemen Sumber Daya Manusia (Edisi Revisi), Jakarta: Bumi Aksara.

17. Heraclides, A. M., Chandola, T., Witte, D. R., \& Brunner, E. J. (2012). Work stress, obesity and the risk of type 2 diabetes: Gender-specific bidirectional effect in the white hall II study. Obesity, 20(2), 428-433. https://doi.org/10.1038/oby.2011.95

18. Herqutanto, Harsono, H., Damayanti, M., \& Setiawati, E. P. (2017). Stres Kerja pada Perawat di Rumah Sakit dan Fasilitas Pelayanan Kesehatan Primer. EJournal Kedokteran Indonesia, 5(1), 12-17. https://doi.org/10.23886/ejki.5.7444.12-7

19. Jaradat, Y.M.M. (2017). Workplace Stress Among Nurses Stressful working conditions, shift work, and workplace aggression among Nurses in Hebron District, West Bank, Palestine, https://www.semanticscholar.org

20. Kaplan \& Sadock, (2015). Synopsis Of Psychiatry: Behavioral Scienes/Cinical/Psychiatri-Elevent Edition

21. Konturek, P. C., Brzozowski, T., \& J, K. S. (2011). Stress and the gut: Pathophysiology, clinical consequences. American Journal of Physiology, 62(6), 591-599. http://www.ncbi.nlm. org/10.5829/idosi.wjns.2015.124.137 nih.gov/pubmed/22314561

22. Li, S., Li, L., Zhu, X., Wang, Y., Zhang, J., Zhao, L., Yang, Y., (2016). Comparison of characteristics of anxiety sensitivity across career stages and its relationship with nursing stress among female nurses in Hunan, China. BMJ Open 2016;6:e010829. doi: 10.1136/bmjopen-2015-010829

23. Lovibond, S.H. \& Lovibond, P.F. (1995). Manual for the Depression Anxiety Stress Scales. (2 ${ }^{\text {nd }}$. Ed.) Sydney: Psychology Foundation. ISBN 7334-1423-0.

24. Olatunji, S.O. \& Mokuolu, B.O. (2014). The Influence of Sex, Marital Status, and Tenure of Service on Job Stress, and Job Satisfaction of Health Workers in a Nigerian Federal Health Institution. African Journals Online (Ajol).

25. Robbins, S.P. \& Judge, T.A. (2017). Organizational Behavior 17th ed, Upper Saddle River, New Jersey: Pearson Education, Inc 
26. Safarpour, H., Sabzevari, S., Delpisheh, A. (2018). Study on the Occupational stress, Job Satisfaction and Job Performance among Hospital Nurses in Ilam, Iran. Journal of Clinical and Diagnostic Research June 2018, DOI: 10.7860/JCDR/2018/27410.11573

27. Stanetić, K., Tesanović, G. (2013). Influence of age and length of service on the level of stress and burnout syndrome. Med Pregl. 2013 Mar-Apr;66(3-4):153-62.

28. Tama, I.P., \& Hardiningtyas, D. (2017). Psikologi Industri Dalam Perspektif Sistem Industri.UB Press, Malang

29. Wati, K., Heriyanto, Mellita, D. (2017). Analisis Perbedaan Gender Terhadap Stres Kerja Pada Aparatur Sipil Negara (ASN) Di Lingkungan Kecamatan Banyuasin III Pangkalan Balai. Bina Darma e-Journal, http://eprints.binadarma.ac.id/id/eprint/3477

30. Widoretno, A.W. (2018). Faktor - Faktor Yang Berhubungan Dengan Stres Kerja Perawat Di Instalasi Rawat Inap Rsj Dr. Radjiman Wediodiningrat Lawang. http://repository.unair.ac.id/id/eprint/70618. 